\title{
A preliminary report on the development of young Indian Eagle Owl Bubo bengalensis (Franklin, 1831) in and around Puducherry, southern India
}

\section{Eric Ramanujam ${ }^{1} \&$ T. Murugavel ${ }^{2}$}

\author{
${ }^{1}$ Principal Investigator (Faunistics), Pitchandikulam Bioresource Centre / Pitchandikulam Forest Consultants, Auroville, \\ Tamil Nadu 605101, India \\ ${ }^{2}$ Core Project Co-ordinator, Trust for Environmental Monitoring and Action Initiating, 101, $4^{\text {th }}$ Street, A I Block, Shanti Colony, Anna Nagar, \\ Chennai, Tamil Nadu 600040, India \\ Email: ${ }^{1}$ ericramanujam @yahoo.co.in; ${ }^{2}$ hawkcuckoo@yahoo.com
}

Date of publication (online): 26 October 2009 Date of publication (print): 26 October 2009 ISSN 0974-7907 (online) | 0974-7893 (print)

Editor: Rajah Jayapal

\section{Manuscript details:}

Ms \# 01762

Received 16 April 2007

Final received 15 October 2009

Finally accepted 15 October 2009

Citation: Ramanujam, M.E. \& T. Murugavel (2009). A preliminary report on the development of young Indian Eagle Owl Bubo bengalensis (Franklin, 1831) in and around Puducherry, southern India. Journal of Threatened Taxa 1(10) 519-524.

Copyright: $\odot$ M. Eric Ramanujam \& T. Murugave 2009. Creative Commons Attribution 3.0 Unported License. JoTT allows unrestricted use of this article in any medium for non-profit purposes, reproduction and distribution by providing adequate credit to the authors and the source of publication.

Author Details: M. ERIC Ramanujam currently involved in biodiversity surveys of vertebrates on the Adyar Poonga Project (wetland restoration) in Chennai. Has previously conducted surveys of the Kaliveli region under the European Commission and UBS projects. Has been researching imagery as a tool to enhance environmental sensitization and has illustrated posters, booklets, journal articles, etc. Has been conducting autecological and ethological investigations on Bubo bengalensis since 1997.

T. MURUGAVEL has been involved in environmenta activism in addition to being an amateur bird watcher and photographer. Currently employed as Professor (English), Sri Venkateswara College of Engineering, Pennalur, Sriperumbudur, Tami Nadu.

Acknowledgement: We are greatly indebted to photographers A. Lakshmikantan and R.T. Sriram for their excellent work in recording the natural history of the Indian Eagle Owl.

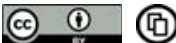

OPEN ACCESS | FREE DOWNLOAD
Abstract: Morphometric, weight and photographic data on the growth patterns of young Bubo bengalensis was obtained in three areas in and around Puducherry. We continuously monitored and observed the growth patterns of nine chicks in total between 10 and 60 days after hatching. Among the morphometric variables, bill and wing chord length showed a mild yet steady increase throughout the observation period, while tarsus length displayed a steep increase till the $20^{\text {th }}$ day, fluctuated till the $40^{\text {th }}$ day and then increased marginally till the $60^{\text {th }}$ day. Body mass showed a steady increase before reaching a plateau between 35 and 45 days, after which only a marginal increase was observed. Chicks were born with whitish natal down. The prejuvenile moult occurred around the $14^{\text {th }}$ or $15^{\text {th }}$ day. Full juvenile plumage was attained by the $35^{\text {th }}$ day and persisted even after 60 days. Morphometric data showed a marked variability, and in this context, ageing of nestlings based on measurements alone may not be accurate and must be complemented with feather moult patterns.

Keywords: Bubo bengalensis, morphometry, nidification

\section{INTRODUCTION}

Growth rates represent a fundamental aspect that can provide information for ageing nestlings in birds. Unfortunately, in spite of their importance in bird population monitoring for environmental degradation, little information on the development of young Strigiformes is available in India. To the best of our knowledge, detailed literature is available only for two species: nidification of Bubo bengalensis (Eates 1937) and morphometry and nidification of Athene brama (Kumar 1985). This is in stark contrast to studies in other parts of the world where Strigiformes are among the best studied taxa for nesting and nidification among birds and many species have been studied in detail - for example, Tyto alba (Sumner 1929; Pickwell 1948; Howell 1964), Otus asio (Sumner 1928, 1929), Otus flammeolus (McCallum et al. 1995), Bubo bubo (Penteriani et al. 2005), Bubo virginianus (Sumner 1929; Hoffmeister \& Setzer 1947), Nyctea scandiaca (Watson 1949), Asio flammeus (Clark 1975; Holt 1992), Strix occidentalis (Forsman 1981), and Ciccaba virgata and Ciccaba nigrolineata (Gerhardt et al. 1994).

This report concerns development of young in the Indian Eagle Owl Bubo bengalensis and presents primary data on morphometry and body weight along with photographic documentation. Though this report could be used as a guide to age young Bubo bengalensis in the region, it must be remembered that this investigation is still preliminary in nature and therefore any generalization of relationships should await corroboration from further studies.

\section{Methods}

Study area: A number of ravines extend from Kalapet $\left(12^{\circ} \mathrm{O} 1^{\prime} \mathrm{N} \& 79^{\circ} 51^{\prime} \mathrm{E}\right)$ near the seashore, southwestwards through the Auroville plateau to the Hermitage - Aranya - Merveille area $\left(11^{\circ} 55^{\prime} \mathrm{N} \& 79^{\circ} 46^{\prime} \mathrm{E}\right)$ adjacent to Ousteri lake - all in a radius of 10 to $15 \mathrm{~km}$ from Puducherry (formerly Pondicherry) city. Though most of these areas are environmental disasters, a few still contain a wealth of biota - including resident breeding Bubo bengalensis.

Field studies centered around four breeding pairs and their young from February 1998 to March 2006. For further details refer Table 1.

Methods: Morphometric measurements were recorded when the young were 10 days old until the young were fully able to fly - i.e., the $60^{\text {th }}$ day. In fact it was difficult after the $35^{\text {th }}$ day to catch the young birds and take measurements as they could glide 
Table 1. Study areas, periods and subjects

\begin{tabular}{lllccc}
\hline & Region \& Study site & Period & $\begin{array}{l}\text { Eggs } \\
\text { laid (N) }\end{array}$ & $\begin{array}{l}\text { Young } \\
\text { Hatched (N) }\end{array}$ & $\begin{array}{l}\text { Young survived } \\
\text { to 60 days (N) }\end{array}$ \\
\hline 1. & Kalapet & Feb. - Apr. 1998 & 3 & 3 & 2 \\
2. & Success Canyon & Jan. - Mar. 2003 & 4 & 4 & 2 \\
3. & Hermitage & Jan. - Mar. 2005 & 4 & 3 & 3 \\
4. & Hermitage & Dec. - Mar. 2006 & 3 & 2 & 2 \\
\hline
\end{tabular}

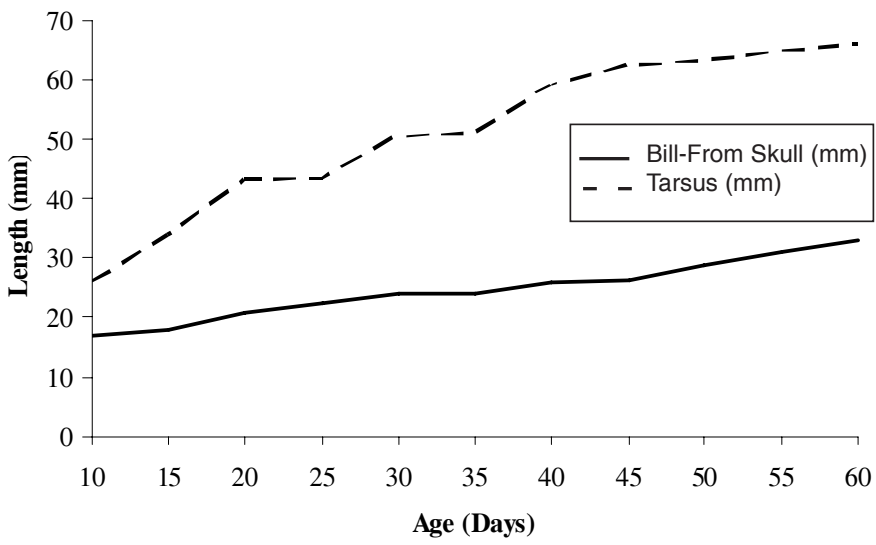

Figure 1. Development of bill and tarsus in young Bubo bengalensis

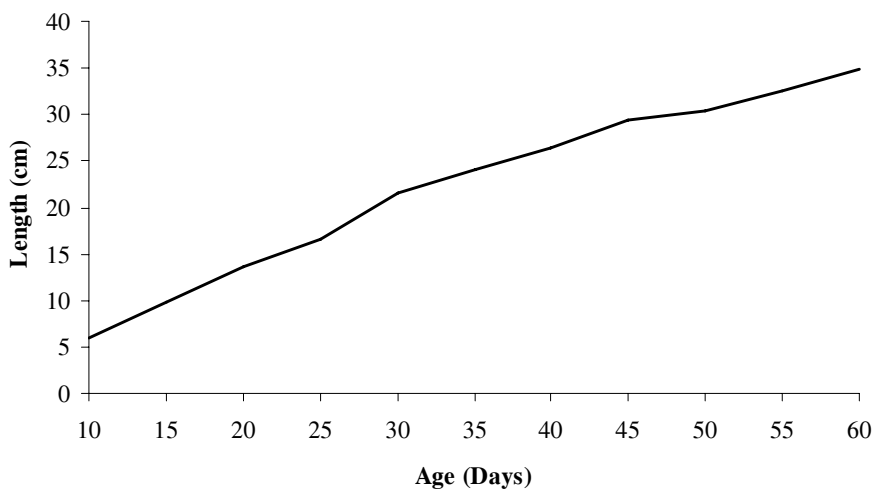

Figure 2. Development of wing in young Bubo bengalensis

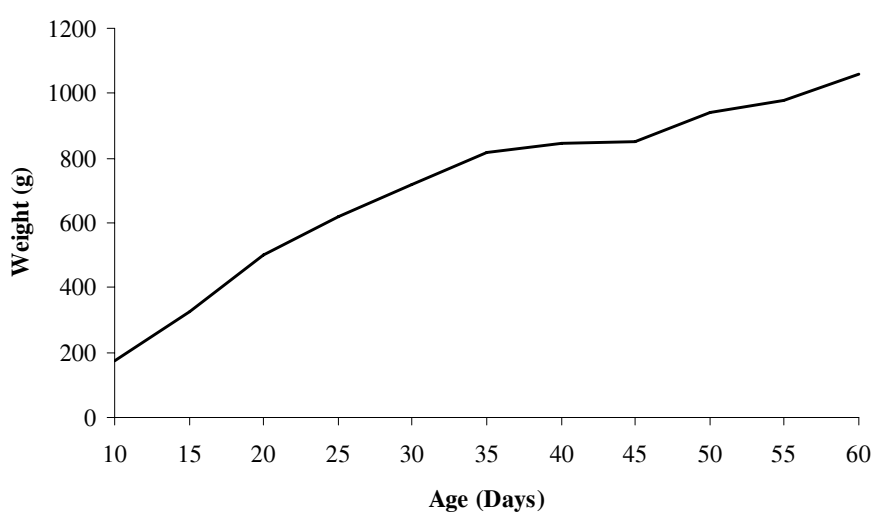

Figure 3. Weight gain in young Bubo bengalensis

and flap away and the terrain made access very difficult. Only nests with chicks at least 10 days old were monitored at close range as new-born owl chicks are known to be very sensitive to human handling. Penteriani et al. (2005) caution against approaching nests of Bubo bubo with chicks less than 15 days old and McCallum et al. (1995) suggest a week's period of habituation for sampling a small cavity nesting owl like Otus flammeolus. Nevertheless, detailed photographic records were made and maintained from the time of egg laying to fledging of chicks.

The following measurements were taken following Ali \& Ripley (1987); only the right tarsus and wing were measured as a matter of convenience.

Wing length $(\mathrm{cm})$ : From the carpal joint to the longest feather along the upper side of the wing. In case of very young birds the wing was pressed out on a ruler, while wing chord was directly measured for older chicks.

Bill length (mm): From skull (lacrimal) to tip of premaxilla.

Tarsus length (mm): From the tibiotarsal joint to the base of the middle toe.

Body weight $(\mathrm{g})$ : Measured using a portable digital balance accurate to $0.01 \mathrm{~g}$.

Differences in growth patterns between sexes were not examined because of the small sample size and difficulty in sexing the chicks.

Plumage descriptions are after Humphrey \& Parkes (1959). To distinguish between chicks non-toxic coloured sprays were used on the birds' under parts near the vent as these were least likely to show in photographs. We do not recommend banding of chicks as parents were observed tugging at plastic bands causing extreme discomfort to chicks.

\section{Results And Discussion}

Young grew rapidly during the first 20 days. Though there was steady monotonic growth throughout the observation period, each morphometric character differed significantly in its growth rate. For example, while bill length showed a steady, yet mild increase in length, the tarsus length recorded a steep increase till the $20^{\text {th }}$ day after which it flattened until the $40^{\text {th }}$ day before it picked up again (Fig 1). The rate of increase in wing chord length was uniform till the $60^{\text {th }}$ day (Fig 2). But body weight showed a steady increase till the $35^{\text {th }}$ day before reaching a plateau between the $35^{\text {th }}$ and $45^{\text {th }}$ day after which there was a marginal spurt in its growth rate (Fig 3). Our extended observations showed that the young completed their growth much later - i.e., over 90 days (when the maximum weight was recorded as $1,373.78 \mathrm{~g}$ ). Such alternate spurts and regression phases in growth factors of chicks make it unreliable to base ageing of nestlings solely on morphometric data. What could be the factors for such wide individual variations? Is it food availability and supply or predation threat or disturbance or is it a normal phenomenon? This would also require a large sample size to standardize ageing criteria. It is further compounded by the fact that the taxon exhibits decreasing clinal variations in body size from north to south (Ali \& Ripley 1987). 
Table 2. Morphometric development and gain in body weight in young Bubo bengalensis from 10 to 60 days. The measurements refer to Mean $\pm S D$ with range in brackets

\begin{tabular}{|c|c|c|c|c|c|}
\hline Age (days) & Subjects (N) & Bill (mm) & Tarsus $(\mathrm{mm})$ & Wing $(\mathrm{cm})$ & Weight (g) \\
\hline 10 & 9 & $17.16 \pm 1.17(15.94-17.42)$ & $26.11 \pm 0.93(25.32-25.96)$ & $5.96 \pm 0.26(5.5-6.3)$ & $175.88 \pm 12.90(152.17-184.24)$ \\
\hline 15 & 9 & $17.89 \pm 0.62(17.01-18.57)$ & $33.96 \pm 0.24(33.53-34.10)$ & $9.80 \pm 0.42(9.1-10.4)$ & $326.25 \pm 23.23(283.89-342.64)$ \\
\hline 20 & 9 & $20.79 \pm 0.72(19.77-21.59)$ & $43.20 \pm 0.31(42.66-43.70)$ & $13.67 \pm 0.58(12.7-14.5)$ & $498.63 \pm 35.51(318.65-523.66)$ \\
\hline 25 & 9 & $22.19 \pm 0.76(21.11-23.04)$ & $43.51 \pm 0.31(42.97-44.02)$ & $16.63 \pm 0.68(15.5-17.6)$ & $617.65 \pm 43.97(537.43-648.65)$ \\
\hline 30 & 9 & $24.01 \pm 0.81(22.82-24.91)$ & $50.56 \pm 0.36(49.94-50.72)$ & $21.53 \pm 0.87(20.1-22.8)$ & $718.19 \pm 51.13(624.93-754.25)$ \\
\hline 35 & 8 & $24.08 \pm 0.79(23-25.09)$ & $51.13 \pm 0.38(50.52-51.75)$ & $24.08 \pm 1.03(22.5-25.5)$ & $817.03 \pm 61.57(708.85-854.80)$ \\
\hline 40 & 7 & $26.15 \pm 0.82(25.51-27.83)$ & $59.20 \pm 0.47(58.53-59.96)$ & $26.34 \pm 1.36(27.4-31.1)$ & $846.00 \pm 68.52(736.53-888.95)$ \\
\hline 45 & 5 & $26.40 \pm 0.58(25.47-26.88)$ & $62.32 \pm 0.27(58.99-59.67)$ & $29.42 \pm 0.25(33.3-33.9)$ & $851.32 \pm 59.18(769.53-905.12)$ \\
\hline 50 & 3 & $28.88 \pm 0.71(25.68-27.10)$ & $63.09 \pm 0.35(61.92-62.57)$ & $30.41 \pm 0.31(33.8-34.4)$ & $940.65 \pm 84.74(842.82-991-33)$ \\
\hline 55 & 2 & $31.25 \pm 0.56(30.25-31.0)$ & $64.93 \pm 0.38(62.93-66.93)$ & $32.50 \pm 0.71(31.50-33.50)$ & $980.15 \pm 85.25(960.20-1000.10)$ \\
\hline 60 & 2 & $33.09 \pm 0.04(31.05-32.04)$ & $65.83 \pm 0.40(62.83-68.83)$ & $34.80 \pm 0.42(34.30-35.30)$ & $1029.85 \pm 118.85(1000.50-1059.20)$ \\
\hline
\end{tabular}

A more reliable way to age young Bubo bengalensis are differences in feather morphology and this is evident from the photographic record:

1. Clutch of five eggs. Three to four is the usual clutch size, but five is not uncommon (Image 1).

2. Chick using egg tooth to break out of egg. The use of this feature is obvious - viz, to chip away the shell between the upper mandible and egg tooth (Image 2).

3. 0-5 day old nestlings. Eggs hatch asynchronously on most occasions. The nidicolous and semi-altrical young are covered in whitish natal down and their eyes are closed. They are semi-ptilopaedic as some parts (back, shoulders and belly) are bare, resulting in pink patches. Nestlings lie prostrate, the belly in contact with the substrate (Image 3).

4. Seven day old nestling. Pre-juvenile moult has begun and sheaths (pin feathers) are visible on the shoulders and wings. The eyes begin to open at 4 days and can be completely opened by this stage. The entire eye is grayish-black in colour (Image 4).

5. Five and 10 day old siblings. The difference in size is because of asynchronous hatching (5 days apart). At 10 days the belly begins to be covered in down and there is no sign of the egg tooth (Image 5).

6. 15 day old nestling. The woolly prejuvenile moult is in progress, though parts of the belly are still bare of feathers. A yellow iris is obvious around the grayish-blue pupil. Ear tufts begin their development. It can adopt the intimidatory posture if threatened, though in a weak manner (Image 6).

7. 20 day old nestling. The entire body is covered in juvenile plumage. The iris is larger and darker (darkness increases with age). Feet and claws start to resemble an adult's. They start to emit a harsh growling hiss like call (Image 7).

8. 25 and 30 day old siblings. At 25 days (subject on the right) the streaked aspect is noticeable. Vibrissa begins to appear. At 30 days (subject on the left) the first streaked appearance is more pronounced (Image 8). The black mask rim appears. Although the elder will continue to be larger, there is not the vast difference in size as was in evidence in Image 5 .

9. 35 day old brancher. The aspect is more like that of an adult due to the eruption of brownish juvenile plumage due to the first prebasic moult. The facial mask is well defined and ear tufts pronounced. Remiges and retrices are well in evidence and form a horizontal bar along the wings. At this stage they move out of the nest and roost away from it. The primaries are well developed and if disturbed they throw themselves off the rock face and glide away making collecting morphometric data difficult, if not impossible (Image 9).

10. 40 days. Tail feathers are pronounced. Feathers are emerging on the nape, head and facial mask. From this stage changes are subtle and ageing from feather pattern becomes difficult (Image 10).

11. 45 days. The first prebasic moult is advanced and the aspect is more like an adult, especially around the nape, facial mask and wings (Image 11).

12. 50 days. First basic plumage is visible on the breast. Wings appear separated in clearly defined bands. A pale downy band contrasts markedly between dark secondaries and upper coverts (Image 12).

13. 55 days. The contrasting downy area on the wings has nearly been replaced (Image 13).

14. 60 days. The undersides are still covered with juvenile down and first basic plumage feathers erupt on the neck and back. The downy underparts contrast markedly with adults, the ear tufts are smaller and iris lighter (Image 14).

15. An adult for comparison (Image 15).

\section{References}

Ali, S. \& S.D. Ripley (1987). Compact Handbook of the Birds of India and Pakistan together with those of Bangladesh, Nepal, Bhutan and Sri Lanka. $2^{\text {nd }}$ edition. Oxford University Press, $737 p p+104$ plates.

Clark, R.J. (1975). A field study of the short-eared owl Asio flammeus (Pontoppidan) in North America. Wildlife Monographs No. 47

Eates, K.R. (1937). The distribution and nidification of the Rock Horned Owl [Bubo bubo bengalensis (Frankl.)] in Sind. Journal of the Bombay Natural History Society 39: 631-633.

Forsman, B. (1981). Molt of the Spotted Owl. The Auk 98: 735-742.

Gerhardt, R.P., N.B. Gonzalzez, D.M. Gerhardt \& C.J. Flatten (1994). Breeding biology and home range of two Ciccaba owls. Wilson Bulletin 106: 629-639.

Hoffmeister, D.F. \& H.W. Setzer (1947). The postnatal development of two broods of great horned owls (Bubo virginianus). University of Kansas Publ. Museum of Natural History 1: 157-173.

Holt, D.W. (1992). Nestling growth rates of Short-eared Owls. Wilson Bulletin 104: 326-333.

Howell, T.R. (1964). Notes on incubation and nestling temperature and behaviour of captive owls. Wilson Bulletin 76: 28-36.

Humphrey, P.S. \& K.C. Parkes (1959). An approach to the study of molts and plumages. The Auk 76: 1-31.

Kumar, T.S. (1985). The Life History of the Spotted Owlet (Athene brama Temminck) in Andhra Pradesh. Monograph of the Raptor Research Centre, Hyderabad, $241 \mathrm{pp}$.

Mathew, K.M. (1981). Materials for Flora of Tamil Nadu-Carnatic. Rapinat Herbarium Publication, Tiruchirapalli.

McCallum, D.A., F.R. Gehlbach \& S.W. Webb (1995). Life history and ecology of flammulated owls in a marginal New Mexico population. Wilson Bulletin 107: 530-537.

Penteriani, V., M.M. Delgado, C. Maggio, A. Aradis \& F. Sergio (2005). 

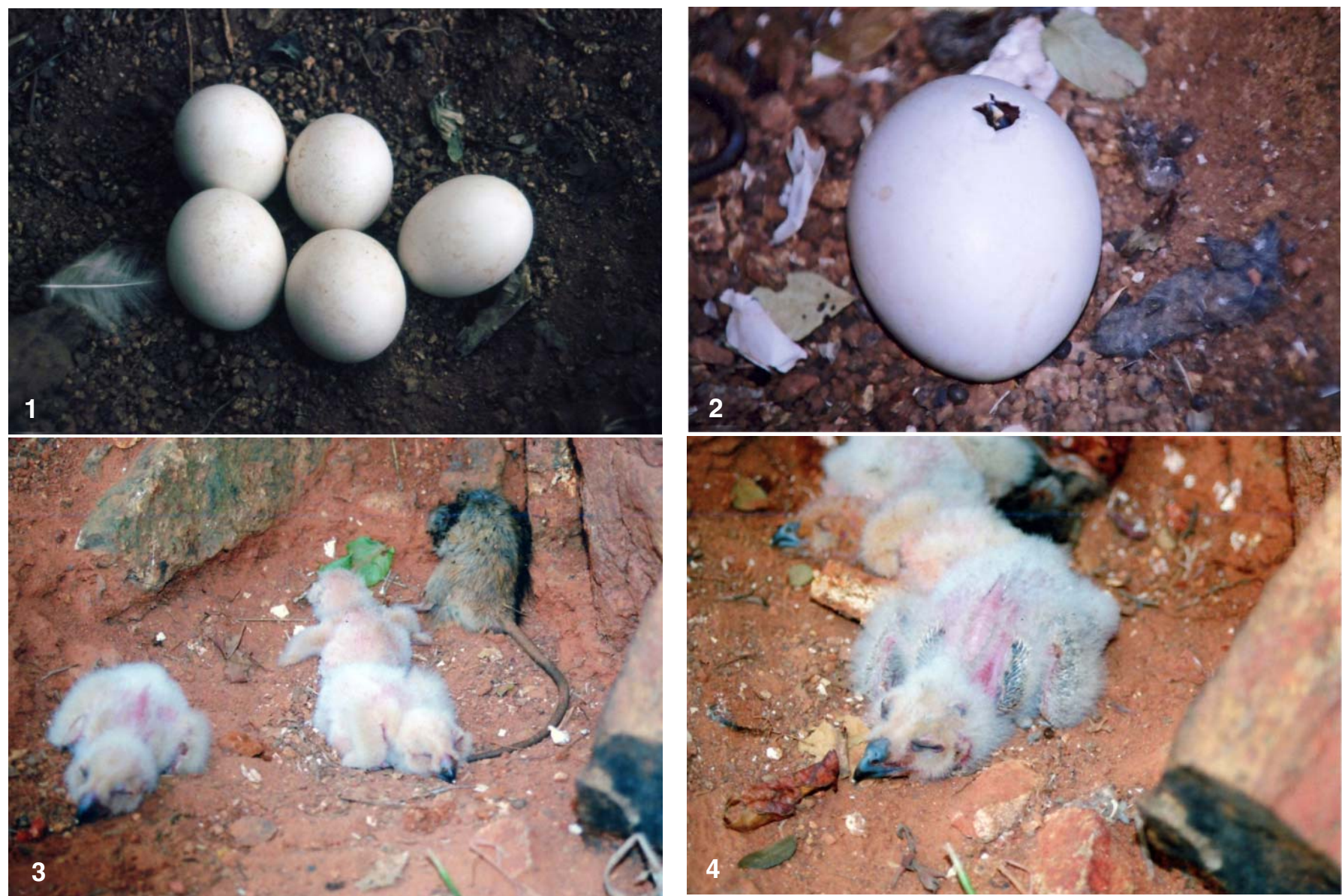

3

$$
2
$$

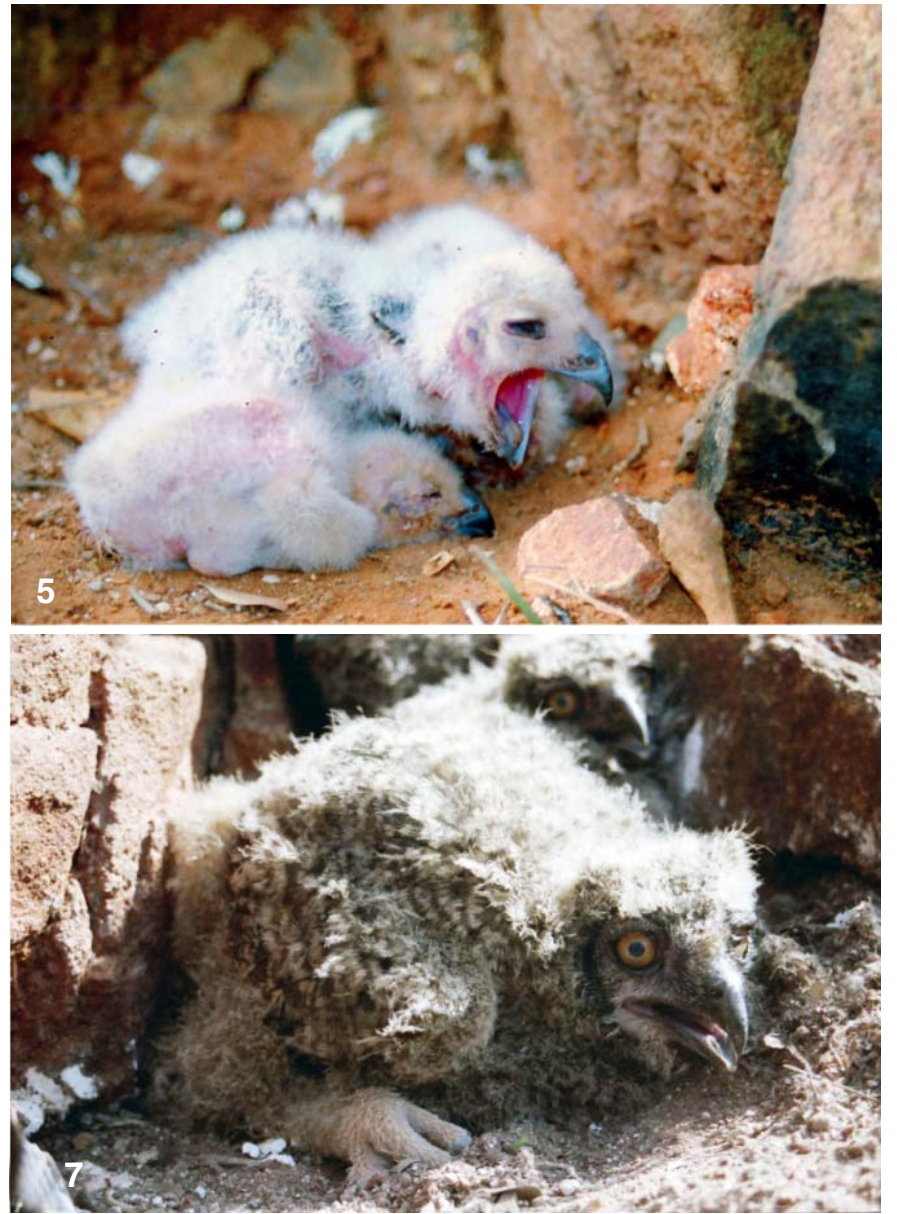

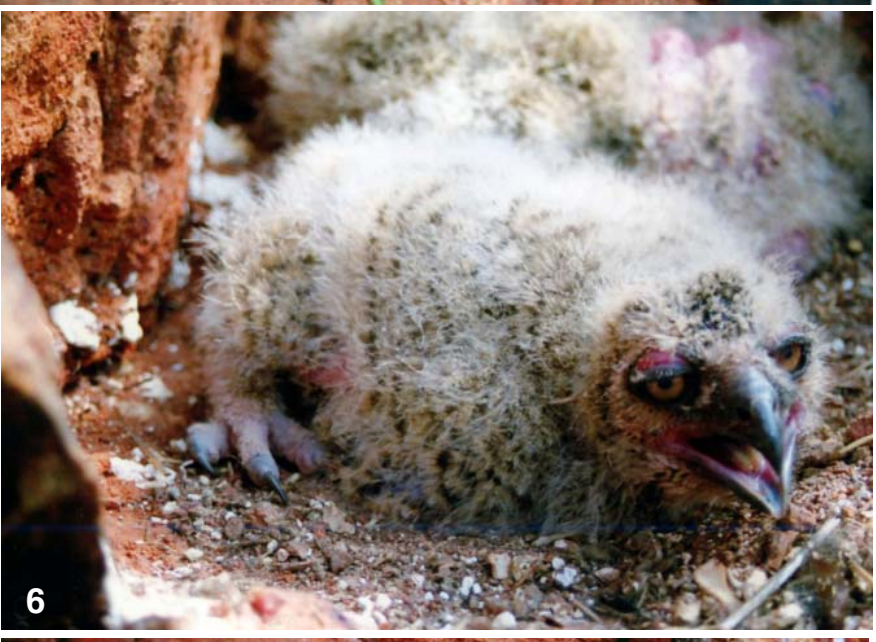

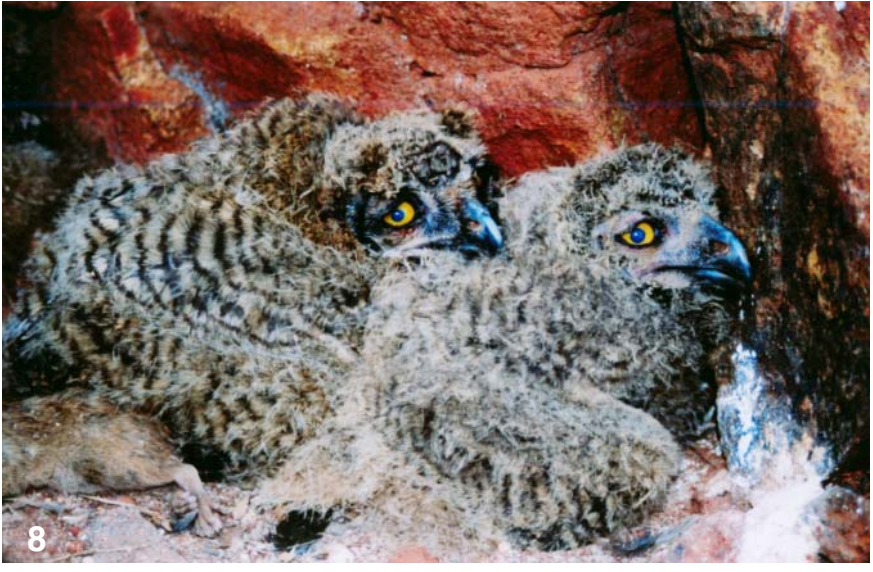



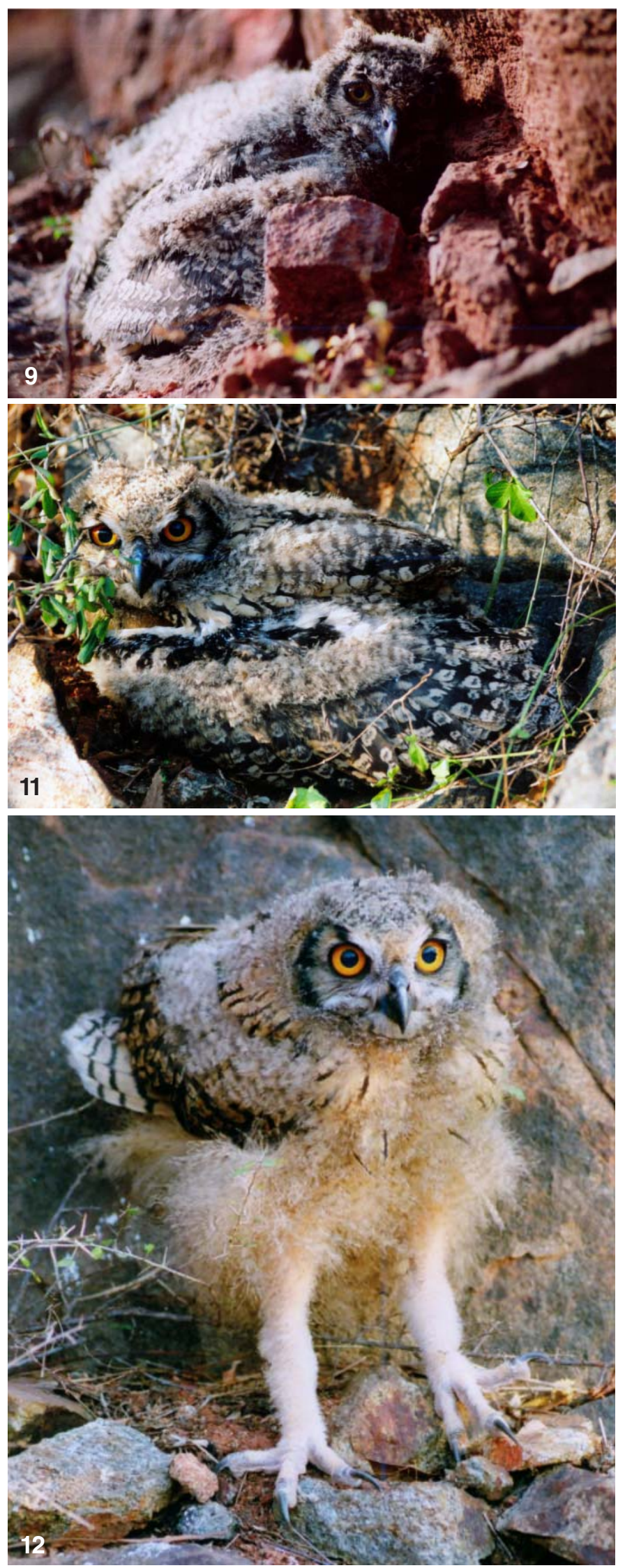
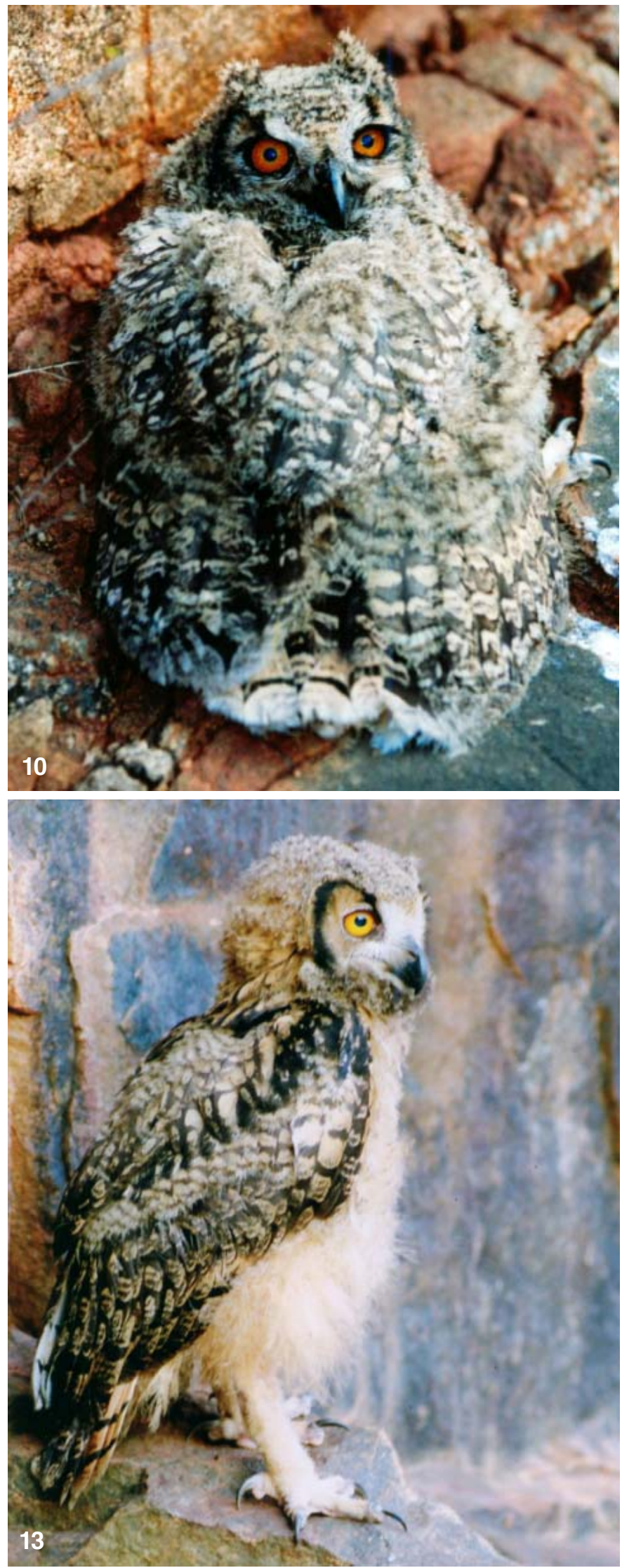

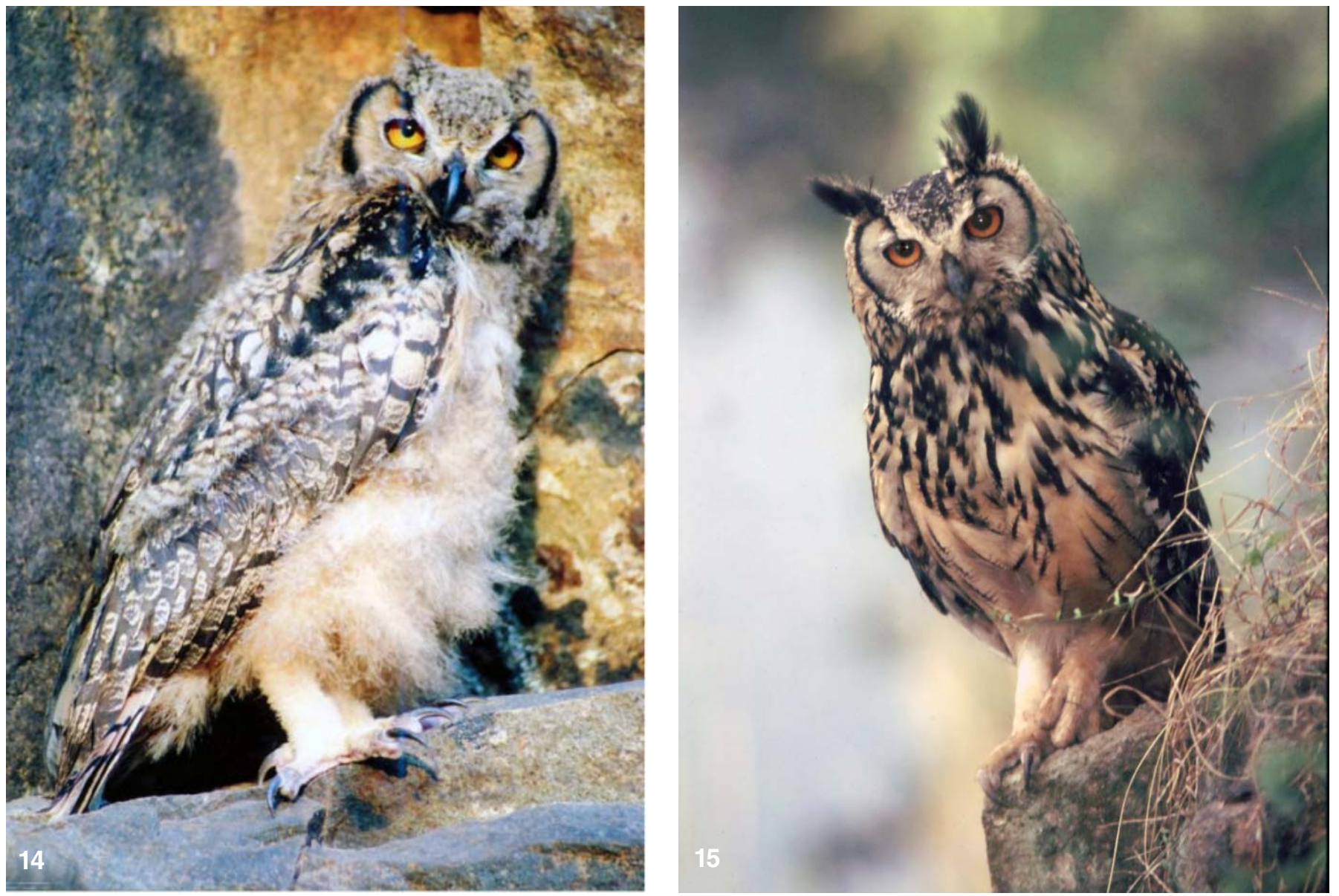

Development of chicks and predispersal behaviour of young in the eagle owl Bubo bubo. Ibis 147: 155-168.

Pickwell, G. (1948). Barn owl growth and behaviourisms. The Auk 65: 359-373.

Sumner, E.L. Jr (1928). Notes on the development of young screech owls. Condor 30: 333-338.

Sumner, E.L. Jr. (1929). Comparitive studies on the growth of young raptors. Condor 31: 85-111.

Watson, A. (1957). The behaviour, breeding, and food-ecology of the Snowy Owl Nyctea scandaica. Ibis 99: 419-462.

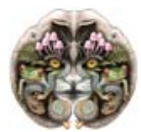

